\title{
INTERNATIONAL CIVIL PROCEDURE IN JAPAN
}

Kono Toshiyuki*

\section{GENERAL CONTEXT ${ }^{1}$}

\subsection{The judicial system ${ }^{2}$}

\subsubsection{Introduction}

All judicial power is vested in the Supreme Court and in such other inferior courts as are established by law. Accordingly, a single judicial hierarchy decides administrative as well as civil and criminal actions. Since Japan is a unitary (non-federal) state, all courts are national courts. Thus the organization and power of the courts are determined by the Japanese Constitution and the national Court Law.

The hierarchy of the courts is as follows: the summary courts are at the bottom, the district courts and the family courts at the second level, the high courts at the third level and the Supreme Court at the top. There is no limitation to the right of appeal from summary courts to district courts, or from district courts, as the courts of first instance, to a high court. A re-appeal may be made to a high court against appellate judgments of the district court, and to the Supreme Court against judgments of either first or second instance rendered by a high court. The grounds for re-appeal in civil cases are restricted to violation or misconstruction of the law or the Constitution.

\subsubsection{Summary Court}

The summary courts are the base of the whole court structure and have power to try civil cases involving small claims. They are the courts of first instance for civil cases involving claims not exceeding 900,000 Yen. In summary courts a single judge decides the case. The court may use judicial com-

\footnotetext{
* Professor of Law, Kyushu University.

' Important articles in this field are included in ANDREAS HELDRICH and KONO TOSHIYUKI (eds.), Herausforderung des Internationalen Verfahrensrecht [The Challenge of the Law on International Procedure] 1994. For an overview, see AOYAMA YoSHIMITSU, 'Problems in international litigation', in Collected Reports of the International Symposium on Civil Justice in the Era of Globalization (1993) 44-63; TANIGUCHI YASUHEI, in BAUM and DROBNIG (eds.), Japanisches Handels- und Wirtschaftsrecht [Japanese Commercial and Economic Law] (1994) ch. 6 sec. 13 pp. 683-689.

${ }^{2}$ HATTORI TAKAAKI and DAN HANNo HeNDERSON, Civil Procedure in Japan (1985) Ch. 1 and 3.

Asian Yearbook of International Law, Volume 6 (Ko Swan Sik et al., eds.

- Kluwer Law International; printed in the Netherlands), pp.105-134
} 
missioners ${ }^{3}$ in effecting a settlement or conducting a hearing. There are special provisions in the Japanese Code of Civil Procedure (CCP ${ }^{4}$ for the simpler character of summary court proceedings. ${ }^{5}$ In 1995, 243,569 civil cases were handled by the summary courts, out of which 112,446 were finished by judgment, 68,267 by settlement and 51,702 by withdrawal. Circa $80 \%$ of the 243,569 cases were finished within three months after the commencement of the litigation. ${ }^{6}$

\subsubsection{District Court/Family Court}

The district courts have general adjudicatory authority over civil cases (including transboundary) and criminal cases as courts of first instance. There is one district court in each of the 47 prefectures, except for Hokkaido which has four such courts. The Supreme Court may establish branches of a district court within its district. Each branch has its own territory and usually hears cases arising therein. The main office remains competent, however, to hear all cases within its territory. The district court bench consists of judges and assistant judges. Usually one judge presides over the court and decides the cases. In exceptional cases a three-judge collegiate court is required. Two kinds of cases require such a collegiate court: appeal cases from summary court judgments, and cases where a collegiate court has ruled that they are to be decided by a collegiate court, upon request of a single judge in a complicated case. In 1995, 146,772 cases were handled by the district court in first instance, out of which 69,951 were finished by judgment, 48,144 by settlement and 22,532 by withdrawal. Around $60 \%$ of the 146,772 cases were finished within 6 months, around $15 \%$ within one year, and around $15 \%$ within two years after the commencement of the procedure. ${ }^{7}$

The family courts rank with the district courts in the judicial system. Family courts specialize in domestic relations and juvenile delinquency. Except for their different competence, family courts are quite similar to district courts. Almost all cases in family courts are heard by a single judge. Laymen often take part in domestic relations cases. When the family court hears domestic cases affecting personal relations or status within a family, family court councillors assist the judge by making recommendations, but they have no vote in deciding the case.

\footnotetext{
${ }^{3}$ Judicial commissioners are all laymen of experience who are appointed in advance every year by the supervising district court. The purpose of this system is to project the common sense of the community into the resolution of disputes and to make justice more accessible to the citizens. See HATTORI and HENDERSON, ibid., ch. 3 p. 9.

${ }^{4}$ A new Code of Civil Procedure (Law No. 109 of 1996) will replace the old CCP (Law No. 29 of 1890) as of 26 June 1998.

${ }^{5}$ E.g. oral complaint (Art. 271 new CCP), no submission of preparatory writings (Art. 276) or a simpler judgment (Art. 280).

${ }^{6}$ Supreme Court, Shiho Tokei [Judicial Statistics] (1996) 96.

${ }^{7}$ Ibid., p. 118.
} 
Conciliation procedures in certain domestic relations cases are mandatory and must be conducted by a conciliation committee. This committee is usually composed of one family court judge and two lay conciliation commissioners appointed by the court.

\subsubsection{High Court}

The high courts are the highest of the lower courts and serve as intermediate appellate courts. They are located in eight large cities. ${ }^{8}$ Some of the high courts with the larger territorial districts have one or two branches. High courts have authority over appeals from district or family court judgments rendered within their respective territories. ${ }^{9}$ From summary court judgments in civil cases, appeals may be brought to the district court and then re-appeal to the high court. All cases in the high court are heard by a three-judge bench. Only the judicial review of the decisions of the Fair Trade Commission and crimes concerning insurrection must be heard by a five-judge bench. In 1995, 15,369 civil cases were handled by the high court as the court of second instance, out of which 8,207 were finished by judgment, 5,455 by settlement and 1,415 by withdrawal. Around $70 \%$ of 15,369 cases were disposed of within one year after the commencement of the procedure. ${ }^{10}$

\subsubsection{Supreme Court}

The Supreme Court is the highest court of Japan, the court of last resort, and the so-called 'Constitutional Court' required by the Japanese Constitution. The Supreme Court exercises appellate competence only. Its main case load consists of appeals from judgments of the high court. The Supreme Court usually sits in three divisions composed of five justices (petty benches). The Grand Bench consists of all 15 justices. All cases filed with the Supreme Court are first assigned by rotation to one of the petty benches. A case is transferred to the Grand Bench, if, in the course of review, it turns out to fall into one of the following categories: (1) when, as a result of the contention of the party concerned, the Court is required to determine whether a law, ordinance, regulation or official disposition is constitutional; (2) when the Court finds, on its own initiative, that a law, ordinance, regulation or official disposition is unconstitutional; (3) when the opinion of the Court (petty bench) in the instant case is contrary to precedent of the Supreme Court on the interpretation or application of the Constitution or any other law; (4) when the opinion of the justices of a petty bench are evenly divided; or (5) when a petty bench deems it appropriate that the case be heard by the Grand Bench. In principle, judgments

\footnotetext{
${ }^{8}$ Tokyo, Osaka, Nagoya, Hiroshima, Fukuoka, Sendai, Sapporo and Takamatsu.

${ }^{9}$ The high courts have original jurisdiction over certain subject matters designated by special laws such as violations of the election law or the crime of insurrection. The Tokyo High Court has jurisdiction to review decisions made by such quasi-judicial agencies as the Fair Trade Commission, the Patent Office, and the Marine Accident Adjustment Agency.

${ }^{10}$ Loc.cit. n. 6 p. 164.
} 
are made by majority. To declare a law or ordinance unconstitutional, a majority of eight in the Grand Bench is required. In 1995, 2,429 civil cases were handled by the Supreme Court, out of which 2,371 cases were finished by judgment, 10 by settlement ${ }^{11}$ and 48 by withdrawal. Around $80 \%$ of the 2,429 cases were finished within one year after the commencement of the procedure. ${ }^{12}$

Mainly because of the heavy case loads of Supreme Court justices ${ }^{13}$ and delays in the lower courts, several ways to reform the court system were proposed. ${ }^{14}$ As a result of the reform of the CCP in 1996, the re-appeal system has been amended. Under the old CCP, there were three main grounds for re-appeal: violation of the Japanese Constitution, violation of laws or ordinances which clearly affects the judgment (old CCP Art. 394) and violation of important procedural rules (as absolute grounds of re-appeal, ${ }^{15}$ old CCP Art. 395). Re-appeal had to be accepted, unless certain formal procedural requirements were not met (old CCP Arts. 399 and 399(3)). Therefore, when a party contended that the judgment of the inferior court suffered from one of the above three deficiencies, and when the re-appeal fulfilled all formal procedural requirements, the Supreme Court must accept the re-appeal and start oral proceedings. In practice, however, the second ground (violation of laws or ordinances which clearly affects the judgment) was often misused. It caused heavy case loads for the Supreme Court and hampered the latter's role in unifying the interpretation of laws and ordinances.

Besides modification of the grounds for re-appeal, the new CCP introduced a new system for re-appeal: "acceptance of the case for re-appeal". Under the new law, there are only two grounds for re-appeal: violation of the Japanese Constitution and violation of important procedural rules. ${ }^{16}$ The often misused ground of violation of laws or ordinances which clearly affects the judgment is no ground for re-appeal to the Supreme Court any more. ${ }^{17}$ When, however, "a judgment of an inferior court might contain important issues concerning the interpretation of laws or ordinances, such as contradiction with the precedents of the Supreme Court", the parties can apply for re-appeal to the Supreme

\footnotetext{
${ }^{11}$ This shows that re-appeal cases are highly complicated.

${ }^{12}$ Loc.cit. n. 6 p. 188.

${ }^{13}$ The number of newly accepted civil and administrative re-appeal cases was 2406 in 1992, 2500 in 1993 and 2726 in 1994.

${ }^{14}$ HATTORI and HENDERSON, op.cit. n. 2 ch. 3 p. 21.

${ }^{15}$ Such absolute grounds for re-appeal were: (1) the court was not lawfully constituted, (2) a judge who should not take part in the procedure did participate, (3) violation of rules on exclusive jurisdiction, (4) incompetence of the representative of the parties to act in the procedure, (5) violation of rules on public trial, and (6) lack of, or contradictions in, reasons given in the judgment.

${ }^{16}$ New CCP, Art. 312. There is no difference between the old and the new CCP list of 'important procedural rules'.

${ }^{17}$ The purpose is to reduce the case load of the Supreme Court. It is still a re-appeal ground to the High Court (Art. 312(2)).
} 
Court. The Supreme Court may accept or refuse the case. By the decision to accept the case, the application is considered a re-appeal (Art. 318).

\subsection{The sources of international civil procedure}

Japanese law has only a few provisions on international procedural matters in the CCP. The Horei (Law No. 10 of 1898 , as amended), regulating private international law, contains no provision on the matter. The number of international treaties that Japan has ratified is quite limited. ${ }^{18}$ Therefore academic theories and case law play an important role. Judicial precedents are relied on by lawyers and courts in applying statutes and court rules to particular cases. The courts are, however, not bound by stare decisis, except that lower courts must follow the Supreme Court precedents and generally they follow their own precedents until overruled by higher courts.

The lex fori, including the CCP and the Rules of Civil Procedure ${ }^{19}$ as primary sources, is in principle also applicable to procedural matters in cases of transboundary litigation. This does not mean that the CCP should be applied to transboundary litigation without any modification. It is argued that in certain matters of transboundary litigation, like those closely connected with substantive law, ${ }^{20}$ foreign law should be taken into consideration in determining procedural matters. ${ }^{21}$

\subsection{The historical background of the CCP and its amendment in $1996^{22}$}

The old CCP referred mainly to the German Code of Civil Procedure of 1877 but also to Prussian and Austrian laws. ${ }^{23}$ It was promulgated in 1890 and came into force in 1891 . In 1927 it was substantially amended. Partial amendments were made several times afterwards. Due to drastic changes in the Japanese economy and society and the complications in litigation since then, gradually the old CCP became less adequate for the current situation in Japan. Therefore a reform was carried out, and on 26 June 1996 a new CCP was promulgated. It will replace the old CCP within two years after promulgation. Not only have several new systems been introduced in the new CCP, but unchanged provisions have been rewritten into modern Japanese so as to make the Code more accessible. This was the reason why the reform was put in the form of a new law.

${ }_{18}$ International treaties can be directly applied by the Japanese court, as far as they are self-executing. They are generally considered superior to national laws.

${ }^{19}$ Technical rules made by the Supreme Court for the implementation of the CCP.

${ }^{20} \mathrm{E}$.g. in which circumstances the standing of the party should be recognized.

${ }^{21}$ See Yamamoto KazUhiKo, 'Kokusai Minji Sosho Ho' [Law of International Civil Procedure], in SAITo Hideo (ed.), Chukai Minji Sosho Ho [Commentary on Civil Procedure Law] Vol.5 (2nd. ed., 1991) 402-422.

${ }^{22}$ MIYAKE HIROTO, 'Comparative legal analysis of the reform of the Code of Civil Procedure', in Collected Reports, op.cit. n. 1 p. 179.

${ }^{23}$ About the history preceding the old CCP, see HATTORI and HENDERSON, op.cit.n.2, ch. 1 p. 28. 
The main features of the new CCP are:

(1) Three new procedures to clarify issues and evidence: preparatory oral proceeding, proceeding-preparing procedure ${ }^{24}$ and proceeding-preparing procedure by documents. ${ }^{25}$

(2) Improvement of procedures for the taking of evidence. ${ }^{26}$

(3) Creation of a special procedure for claims not exceeding 300,000 Yen. ${ }^{27}$

(4) Modification of the system of re-appeal to the Supreme Court.

\section{JURISDICTION ${ }^{28}$}

\subsection{The notion of jurisdiction}

\subsubsection{Jurisdiction in the sense of 'Kankatsu-ken'}

In this context, 'Saiban-ken' and 'Kankatsu-ken' should be distinguished. Saiban-ken denotes comprehensively the power to adjudicate legal disputes and to enforce decisions. ${ }^{29}$ It constitutes the main portion of the judicial power (Shiho-ken) prescribed by the Japanese Constitution and can be limited only by that Constitution and by international law.

Kankatsu-ken, on the other hand, presupposes the existence of Saiban-ken. It is the Japanese equivalent of Zuständigkeit, as used in German law to refer to a specific portion of the judicial competence. In transboundary civil litigation it defines if and how Japanese courts are authorized to exercise Saiban-ken, ${ }^{30}$ while in regular domestic civil litigation it is assigned to a particular court as a

\footnotetext{
${ }^{24}$ The difference between the preparatory oral proceeding and the proceeding-preparing procedure is as follows: the preparatory oral proceeding is an oral proceeding for the purpose of sorting out and clarifying the issues and the evidence (Arts. 164-167). It takes place in the court room and is open to the public. The court which handles the case also presides over the procedure during which any kind of acts regarding the sorting out and clarifying of issues and evidence may be conducted. The proceeding-preparing procedure, on the other hand, takes place at another place, such as the room for settlement or even the judge's chambers. The procedure is not necessarily open to the public, although the parties may require the attendance of certain people. Due to its nature, the kinds of acts allowed under this procedure are limited, for example regarding the examination of testimony. The procedure can be conducted by a judge exclusively appointed for this purpose, or by a telephone conference system (Arts. 168-174).

${ }^{25}$ This is the proceeding-preparing procedure without attendance of the parties. It is mainly available for those who live far from the seat of the court (Arts. 175-178).

${ }^{26}$ E.g. the court may order the parties to produce more kinds of documents (Art. 220).

${ }^{27}$ This is a summary court procedure. The claim can be brought orally to the court. The oral proceeding takes place only once and judgment is rendered right after it. The procedure is dependent of the plaintiff's option. Otherwise the case will be treated according to the ordinary summary court procedure (Arts. 270-280).

${ }^{28}$ Besides HELDRICH and KONO, op.cit. n. 1, see also NOMURA YOSHIAKI, 'Japanese court jurisdiction in transnational litigation', 21 Osaka University Law Review (1984) 31.

${ }^{29}$ HATTORI and HENDERSON, op.cit. n. 2, ch. 4 p. 4.

${ }^{30}$ Ibid.
} 
limited portion of Saiban-ken. ${ }^{31}$ Therefore, Kankatsu-ken is regulated in principle by national laws. In this paper 'jurisdiction' will be used in the sense of Kankatsu-ken. Kankatsu-ken and Saiban-ken should be theoretically distinguished, but court decisions often use the word Saiban-ken in the sense of Kankatsu-ken or do not clearly distinguish between the two. ${ }^{32}$

\subsubsection{How to determine international jurisdiction?}

According to unanimous opinion in case law and academic doctrine, there is no provision on international jurisdiction in Japanese law, and, to fill this lacuna, the notion of 'Jori' should be used. ${ }^{33}$ Jori is a notion similar to justice, meaning "fairness between parties and speedy and appropriate judgment". ${ }^{34}$ Although this is the unanimous understanding of Jori in its abstract content, it is not clear how to determine whether jurisdiction can be exercised in concrete cases. The following theories have been proposed as to possible criteria:

(1) Jurisdiction acquired under a provision of the CCP implies jurisdiction for transboundary cases. ${ }^{35}$ In other words, according to this theory the contents of Jori is contained in the CCP. The theory does not allow any jurisdiction which is not based on the CCP. This theory seems contradictory to me: it says that there is no provision on international jurisdiction in the Japanese law, but at the same time it says that Jori as contained in the CCP should be applied. In my opinion, this is practically the same as saying that the CCP regulates not only domestic, but also transboundary jurisdiction. The theoretical advantage of this theory is not clear to me. The judgment of the Supreme Court in the so-called Malaysian Airline case $e^{36}$ seems to adhere to this theory.

(2) The leading opinion is that, since there is no provision on international jurisdiction in the CCP, special jurisdiction rules for specific types of transboundary cases should be created based on international considerations. ${ }^{37}$ Although this theory looks different from the first one, it refers so often to provisions of the CCP that it leads to similar results.

${ }^{31}$ Kankatsu-ken for domestic civil litigation is further sub-divided into three categories: Shokubun-kankatsu (functional competence: e.g. some cases must be brought in the family court because of their nature), Jibutsu-kankatsu (subject matter competence: claims not exceeding 900,000 Yen go to the summary court), and Tochi-kankatsu (territorial competence: this indicates the geographical district where an action must be commenced). Cf. ibid., ch. 4 p. 6.

${ }^{32}$ E.g. Supreme Court 16 October 1981, 35 Minshu No. 7 p. 1224 (English translation in 26 JAIL (1983) 122).

${ }^{33}$ Ibid. See also, IKEHARA SUEO, 'Kokusaiteki Saiban Kankatsu-ken' [International Jurisdiction], in

7 Shin Jitsumu Minji Sosho Ho Koza [New Series of Practice of Civil Procedure] (1982) 14.

${ }^{34}$ Supreme Court, loc.cit. n. 32.

${ }^{35}$ EgAWA HIDEFUMI, 'Kokusai Shiho ni okeru Saiban Kankatsu-ken' [Jurisdiction in private international law], Hogaku Kyokai Zasshi [Journal of the Jurisprudence Association, University of Tokyo] Vol.60 No.3 (1942) 374.

${ }^{36}$ Loc.cit.n. 32

${ }^{37}$ IKEHARA, loc.cit.n. 33 p.22. See also Tokyo District Court 15 February 1984, Hanrei Taimuzu No. 525 p. 132 (English translation in 28 JAIL (1985) 243) and cf. Tokyo District Court 20 March 1979, Hanreijiho No. 925 p. 78 (English translation in 24 JAIL (1981) 127). 
(3) Specific rules should be created on a case by case basis, whereby concrete circumstances in each individual case, such as close connection between the case and the forum or protection of the weaker party, should be taken into consideration. ${ }^{38}$ This third theory is criticized as the results are unpredictable.

(4) The rule on international jurisdiction is in principle determined under the provisions of the CCP. Exceptions can be made by taking into consideration 'special circumstances' in each individual case. Lower courts started to use this test $^{39}$ after the judgment of the Supreme Court in the Malaysian Airline case and some scholars elaborated it as a theory. ${ }^{40}$ This theory offers the possibility to modify the jurisdiction rules of the CCP. A broad interpretation of 'special circumstances', the taking into consideration of the many elements of an individual case and the creation of exceptional rules for each individual case, may, however, lead to unpredictable results.

As the comment on each theory shows, a choice in favour of one theory does not automatically lead to clear-cut results. The important thing is not to select one theory, but to examine individual jurisdiction rules and their theoretical backgrounds.

\subsection{The exercise of jurisdiction}

\subsubsection{Requirements}

In this section we shall deal with jurisdiction rules for specific types of cases.

(1) The court at the place of the defendant's domicile is entitled to exercise jurisdiction. This rule applies to all types of transboundary cases. If the defendant has his domicile in a foreign country and only his residence in Japan, a Japanese court may not exercise jurisdiction. ${ }^{41}$

Recently, however, the Supreme Court confirmed jurisdiction of the Japanese court in a case where the defendant had her domicile exclusively in Germany. ${ }^{42}$ The German wife of a Japanese husband had filed a claim for divorce with a German court, which admitted the claim. Then the Japanese husband filed a claim for divorce in a Japanese court, where the German wife raised the exception of lack of jurisdiction. According to the Supreme Court, the case should be distinguished from the ones in which the jurisdiction of the Japanese court was recognized on the basis of special circumstances, ${ }^{43}$ such as the fact

\footnotetext{
${ }^{38}$ ISHIGURO KAZUNORI, Gendai Kokusai Shiho [Contemporary Private International Law] Vol.1 (1986) 291.

${ }^{39}$ E.g. Tokyo District Court 27 September 1982, Hanrei Taimuzu No. 487 p. 167 (English translation in 27 JAIL (1984) 174); Tokyo District Court 27 March 1989, Hanreijiho No. 1318 p. 82 (English translation in 33 JAIL (1990) 199).

${ }^{40}$ E.g. KOBAYASHI HIDEYUKI, Kokusai Torihiki Funso [International Trade Disputes] (1987) 116.

${ }^{41}$ YAMAMOTO, loc.cit. n. 21 p. 443.

${ }^{42}$ Supreme Court 24 June 1996, Hanreijiho No.1578 p.56.

${ }^{43}$ Supreme Court 25 March 1962, 18 Minshu No.3 p.486; Nagoya High Court 30 May 1995, 891 Hanrei Taimuzu p. 248.
} 
that the plaintiff was abandoned or that the defendant's domicile is unknown or even abroad. In order to recognize jurisdiction of the Japanese court in the above recent case, not only the defendant's interest, i.e. not being forced to appear before a foreign court, but also the plaintiff's interest, i.e. being entitled to sue, should be taken into consideration, as well as the legal or practical obstacles involved in a foreign forum. The German divorce judgment would not be eligible for recognition in Japan, since service was conducted by way of public notice, while a claim of the Japanese husband would be dismissed in Germany due to res judicata of the earlier German divorce judgment. In order to protect the plaintiff's interest, i.e. his right to sue, the Japanese court should exercise jurisdiction.

The judgment should be criticized, however, since, following this judgment, the Japanese court may take cognizance of lawsuits without referring to any jurisdiction rule, merely based on the fact that the foreign judgment cannot be recognized in Japan. The last domicile in Japan of a person who has no domicile nor residence in any country cannot be a ground of jurisdiction either. ${ }^{44}$

The principal place of business of a corporation determines jurisdiction in all types of cases. ${ }^{45}$ An office which has nothing to do with the case does not suffice for the Japanese court to exercise jurisdiction, although in some cases the courts have nevertheless asserted jurisdiction. ${ }^{46}$ The general rule cedes to special rules in case of applicability of the Convention on Civil Liability for Oil Pollution Damage (1969) or the Convention for Unification of Certain Rules relating to International Transportation by Air (1953) and the additional Protocol (1967).

(2) The place of performance ${ }^{47}$ may determine jurisdiction only in case of contract-related $^{48}$ disputes and only when the place of performance can be clearly identified from the contract. ${ }^{49}$ The rule should not be applied to monetary obligations. Since the place of performance of a monetary obligation is often not closely connected to the contract itself, such as when chosen for tax or other reasons, the evidence available at the place of performance is usually less decisive.$^{50}$ However, case law tends to take a more generous attitude. ${ }^{51}$

\footnotetext{
${ }^{44}$ DogaUCHI MASATO, 'Kokusaiteki Saiban Kankatsu-ken' [International Jurisdiction], in SHINDO KOJI and KoJIMA TAKESHI (eds.), Chushaku Minji Soshoho [Commentary on International Civil Procedure] (1991) 111.

${ }^{45}$ Ibid.

${ }^{46}$ Supreme Court, supra n. 32. Also, Tokyo District Court 27 September 1982, Hanreijiho No. 1113 p. 137 (English translation in 27 JAIL (1984) 174).

${ }^{47}$ According to Tokyo District Court 30 August 1995, Hanrei Taimuzu No. 909 p. 270, the place of performance should in principle be determined by applying Art. 484 of the Japanese Civil Code and, consequently, the place of obligee's domicile is the place of performance. To determine his domicile, his house number should be specified.

${ }^{48}$ This means that the rule does not apply to tort cases.

${ }^{49}$ YAMAMOTO, loc.cit. n. 21.

${ }^{50}$ DOGAUCHI, loc.cit. n. 44.

${ }^{51}$ Interlocutory judgment Tokyo District Court 27 November 1981, Hanrei Taimuzu No. 460 p. 118.
} 
(3) The place of tort determines jurisdiction in tort cases. ${ }^{52}$ It can be the place of the tortuous act or the place of occurrence of the damage. ${ }^{53}$ In the latter case, indirect damage such as economic loss caused by physical damage should be excluded, since it would lead to jurisdiction based on the place of domicile of the injured (plaintiff!). The rule should also apply to product liability cases.

(4) The action for negative declaratory judgment, in which it is declared with res judicata effect that party A (plaintiff) is not liable, is often used as a counter- or preventive measure against lawsuits in a foreign forum where party $\mathrm{A}$ is the defendant. Although the parties and the type of case (e.g. product liability case) are the same, the parties change their roles in the lawsuit (i.e. the defendant in the foreign case becomes the plaintiff with an action for negative declaratory judgment case in Japan). The inferior courts tend to apply the same jurisdiction rule to normal product liability cases and to actions for negative declaratory judgment, exercising jurisdiction as the court of the place of tort. ${ }^{54}$ As a result, the plaintiff in the action for negative declaratory judgment in Japan can obtain such a judgment with res judicata effect to protect himself against a lawsuit by the opposing party in a foreign forum. This tendency has been criticized: although the rule of jurisdiction by reference to the place of the tort is originally intended to serve the interest of the injured person, it has come to serve rather the interests of the manufacturer through the action for negative declaratory judgment.

Under Article 8 of the old CCP (Art.5(4) of the new CCP), ${ }^{55}$ when the obligation relating to a "property right" forms "the object of the claim", the place of the obligor's domicile is understood to be the place where the obligation is "situated". If this rule would apply also to an action for negative declaratory judgment, the plaintiff (obligor) would be able to bring the action against his obligee before the court at the place of his domicile. This would be unfair, ${ }^{56}$ as the Tokyo District Court pointed out in its judgment. ${ }^{57}$

\footnotetext{
${ }^{52}$ E.g. interlocutory judgment of the Tokyo District Court 27 October 1995, Hanrei Taimuzu No. 891 p. 71 (plaintiff: the US Government, defendant: a US company, place of tort: Japan).

${ }^{53}$ Tokyo District Court 15 February 1984, Hanrei Taimuzu No. 525 p. 132 (English translation in 28 JAIL (1985) 243).

${ }^{54}$ Tokyo District Court 27 March 1984, Hanreijiho No. 1113 p.26 (English translation in 28 JAIL (1985) 248); Tokyo District Court 30 May 1989, Hanrei Taimuzu No. 703 p. 240; Tokyo District Court 19 June 1989, ibid.p.246 (English translation in 33 JAIL (1990) 202). See also the interlocutory judgment of the Tokyo District Court of 28 August 1989, Hanreijiho No. 1338 p.121 (English translation in 33 JAIL (1990) 206).

${ }^{55}$ An action concerning a property right against a person who does not live in Japan or whose abode is unknown may be brought in the judicial district where the object of the claim, or a security thereof, or any seizable property of the defendant, is situated.

${ }^{56} \mathrm{See}$, for a different opinion, YАМАмОТО, loc.cit. n. 21 p. 444.

${ }^{57}$ Tokyo District Court 28 July 1987, Hanreijiho No.1275 p.77 (English translation in 32 JAIL (1989) 161).
} 


\subsubsection{Exercise of jurisdiction in case of non-fulfilment of requirements}

This section deals with rules on the exercise of jurisdiction, even if the above-mentioned requirements are not fulfilled.

\section{(1) Joinder of claims}

This notion can be sub-divided into joinder of claims as a multiplicity of objects in a suit, and joinder of parties as a multiplicity of subjects in a suit.

According to the majority opinion, in order to exercise jurisdiction based on joinder of claims, a mutual relevance between the claims is required. ${ }^{58}$ Set-off claims can also be treated as joinder of claims. As for joinder of parties, opinions differ: according to a negative opinion, ${ }^{59}$ if jurisdiction is based on the joinder of parties, a co-defendant would be forced to participate in a procedure before an unexpected forum. On the other hand, a positive opinion says that jurisdiction based on the joinder of parties should be exercised when the rights or liabilities which are the key issues of the claims are common to the various parties, or when the rights or liabilities of both claims are based on common facts and laws. ${ }^{60}$ Case law tends to follow the positive opinion. ${ }^{61}$

\section{(2) Appearance}

As far as it does not violate the exclusive jurisdiction of another forum, jurisdiction may be exercised on the basis of appearance. This rule shares its theoretical basis with the rule of forum selection.

\subsubsection{Jurisdiction to enjoin and to arrest}

In Japanese law, injunction or arrest does not create a ground for jurisdiction. The issue here is rather what requirements should be fulfilled in order to enable the court to order injunction or arrest. The forum which has jurisdiction over the merits should be able to exercise jurisdiction over the question of injunction/arrest. ${ }^{62}$ In fact in a number of cases the court exercised jurisdiction over injunction or arrest after they asserted jurisdiction over the merits. ${ }^{63}$ In

\footnotetext{
${ }^{58}$ DogaUCHI, loc.cit. n. 44 p. 117; YAMAMOTO, loc.cit. n. 21 p. 445; TAKAHASHI HiROSHI, 'Kokusai Saiban Kanktsu' [International Jurisdiction], in AOYAMA YOSHIMITSU and SAWAKI TAKAO (eds.), Kokusai Minji Sosho no Riron [Theories on International Civil Procedure] (1987) 64. See also Tokyo District Court 23 October 1987, Hanreijiho No.1261 p.48; Tokyo District Court 27 March 1989, Hanrei Taimuzu No. 703 p. 240; Tokyo District Court 19 June 1989, ibid. p. 246.

${ }^{59}$ DOGAUCHI, loc.cit.n. 44 p. 118.

${ }^{60}$ YAMAMOTO, loc.cit.n. 21 p. 445 . For a similar opinion, see KIDANA SHOICHI, MATSUOKA HIROSHI and WATANABE SATOSHI, Kokusaishiho Gairon [Compendium of Private International Law] (2nd ed., 1991) 256.

${ }^{61}$ Tokyo District Court 8 May 1986, Hanreijiho No.1196 p.87 (English translation in 31 JAIL (1988) 220); Tokyo District Court 1 June 1987, Hanreijiho No.1261 p.105.

${ }^{62}$ DOGAUCHI, loc.cit. n. 44 p. 120.

${ }^{63}$ Tokyo District Court 26 April 1965, 16 Rominshu No.2 p.308; Yokohama District Court
} 
addition, when assets of the defendant are (even temporarily) located in Japan, the Japanese court should be able to exercise jurisdiction over the question of injunction/arrest on the basis of the mere fact of their location. ${ }^{64}$ Otherwise the enforcement of the ultimate decision may not be secured.

\subsubsection{Jurisdiction in rem and quasi in rem}

Japanese law in general does not know these notions. The function of Article 8 of the old CCP (Art.5(4) new CCP) is, however, similar to that of jurisdiction quasi in rem, although, in contradistinction to the common law rule, the jurisdiction is not limited to the assets. But in transboundary cases, the Japanese court may exercise jurisdiction only if the object of the claim consists of the assets, on the basis of their location. Otherwise such jurisdiction would be excessive.

In relation to real property the court of the place of location has exclusive jurisdiction.

\subsubsection{Constraints on exercise: special circumstance test}

Apart from a rigid standpoint as represented by the above-mentioned first theory (2.1.2.), it is generally admitted that the jurisdiction rule may be modified based on the circumstances of each case. A 'special circumstance test' has been developed by the lower courts and is adhered to by some scholars. ${ }^{65}$ This test has both a negative and an affirmative function. The latter is that when the Japanese court finds itself without jurisdiction but if this would lead to a situation where the plaintiff would have no forum at all, the Japanese court should exercise jurisdiction based on the special circumstances of the case. An example of the negative function is that when no judicial assistance is available due to lack of diplomatic relations between Japan and the country where important evidence is available, the court may consider Japan an inappropriate forum and refuse to exercise jurisdiction. ${ }^{66}$

Although the test offers the possibility of a flexible solution, there is a risk that 'special circumstances' is too extensively interpreted and thus practically plays the principal role in determining jurisdiction. In fact, the generally used criteria of this test, i.e. fairness between the parties and speedy and appropriate

29 September 1966, 17 Kaminshu No.9-10 p. 874.

${ }^{64}$ WATANABE SATOSHI on international jurisdiction over arrest, in IKEHARA SUEO and HAYATA YOSHIRO (eds.), Shogai Hanrei Hyakusen [100 Selected Judgments in the Field of Private International Law] (3rd ed., 1996) 209.

${ }^{65}$ See supra 2.1.2, theory 4 .

${ }^{66}$ As to the negative function, the test has a function similar to that of the forum non conveniens test in US law. Different from the forum non conveniens test, however, the existence of another forum which has jurisdiction over the case is not required. Moreover, the criteria of the special circumstance test (fair, speedy and appropriate judgement) are not as flexible as the criterion of the American test. In addition, using the Japanese test, the court in fact cannot react in a really flexible manner (cf. stay); it must either affirm or refuse to exercise jurisdiction. DOGAUCHI, loc.cit. n. 44 p. 109. 
proceeding ${ }^{67}$, are identical to the abstract contents of Jori. ${ }^{68}$ This would mean that the criteria of the most fundamental guideline for the determination of international jurisdiction and the criteria for exceptional and individual solutions are the same. The 'special circumstance' test would then practically obtain the character of a general rule and most existing jurisdiction rules might be replaced by it. This would lead to an uncertain and unpredictable situation.

\subsection{Forum Selection}

Forum selection is generally recognized as a basis of jurisdiction. Such a selection may raise various questions, such as those on the existence and the validity of the forum selection agreement. In order to find an answer to these questions, the applicable law must be determined. According to the leading opinion, the applicable law is the lex fori. In case of selection in favour of a Japanese forum, the lex fori would thus be the Japanese law on international civil procedure. ${ }^{69}$ Since there is no provision in the CCP on this matter, Article 25 of the old (Art. 11 new) CCP should apply mutatis mutandis. This provision requires that the agreement on forum selection should be made in the form of a document. If this were taken literally, both offer and acceptance should be contained in one document. However, the Supreme Court modified the requirement by ruling that it is not necessary to have both offer and acceptance in one document. ${ }^{70}$ The requirement is deemed to be fulfilled when one party makes a manifest designation of a court in a specific country. This view of the Supreme Court is generally accepted by the literature. ${ }^{71}$ Some scholars try to make the requirement much less strict by taking the position that the designation of a country (without mentioning a court) should suffice. ${ }^{72}$

In the above-mentioned case, the Supreme Court recognized exclusive jurisdiction of a foreign court based on agreement of the parties, provided that the Japanese court does not have exclusive jurisdiction over the case and that the country of the agreed forum exercises its jurisdiction based on its own law. Reciprocity is not required. Nor is it necessary that a judgment rendered in the agreed forum can be recognized and enforced in Japan.

If the forum selection would violate Japanese public policy, jurisdiction should be denied. In addition, the 'special circumstance' test may be used to modify a forum selection.

${ }^{67}$ E.g. Tokyo District Court 20 June 1986, Hanreijiho No.1196 p.87 (English translation in 31 JAIL (1988) 216); Tokyo District Court, Hachioji Branch 22 May 1991, Hanrei Taimuzu No.755 p. 213.

${ }^{68}$ See the Supreme Court in the Malaysian Airlines case, supra n. 32.

${ }^{69}$ DOGAUCHI, loc.cit. n. 44 p. 112.

${ }^{70}$ Supreme Court 28 November 1975, 29 Minshu No. 10 p. 1554.

${ }^{71}$ MITSUKI MASATSUGU, 'Goi Kankatsu' [Jurisdiction Agreement], in SAWAKI TAKAO and AKIBA JUNICHI (eds.), Kokusaishiho no Soten [Issues of Private International Law] (new ed., 1996) 231.

${ }^{72}$ E.g. DOGAUCHI, loc.cit. n. 44 p. 113. 


\subsection{Lis (alibi) pendens ${ }^{73}$}

There are two typical cases of lis alibi pendens. In the first, the same plaintiff files a suit against the same defendant in another forum. In this case the plaintiff's purpose is to secure his claim by instituting more than one litigation. In the second, the defendant in the original litigation (original defendant) files a suit against the original plaintiff. In this case the original defendant's purpose is to shift the forum to the place where he can proceed with the litigation more conveniently, or protect his assets by obtaining a negative declaratory judgment.

While for domestic cases, Article 142 of the new CCP (Art. 231 of the old $\mathrm{CCP}$ ) allows only one litigation, there is neither a municipal nor a treaty provision covering the matter for transboundary litigation. If, however, several litigations in several fora were allowed, the burden on parties could become too heavy, and, moreover, the litigations could lead to contradictory results. It is not possible to await the developments in the other forum, since Japanese law does not provide for the possibility of a procedural 'stay' whereby the procedure is temporarily suspended. Consequently, there has been a discussion on if and how to regulate lis alibi pendens.

Earlier court decisions have ignored the pending litigation abroad and have allowed litigation in Japan, even where the foreign litigation had commenced earlier. ${ }^{74}$ More recent judgments tend to have better understood the issue or, at least, to have taken the issue into consideration. ${ }^{75}$ As for doctrine, there are two opinions. The first one says that if a judgment to be rendered in a foreign litigation would be eligible for recognition in Japan, that litigation should be considered as a Japanese one and, consequently, no new claim before the Japanese court should be allowed. ${ }^{76}$ According to this view, the time element is important for the determination which (i.e. the Japanese or the foreign) litigation should be granted priority. The second view says that lis alibi pendens is inevitable under the current system of civil procedure in the world, and that it can be taken into consideration only as a factor to determine which forum has the closest relationship with the case. For this purpose, the court must have broad discretion. ${ }^{77}$

\footnotetext{
${ }^{73}$ See SAWAKI TAKaO, 'Battle of Lawsuits', 23 JAIL (1980) 17.

${ }^{74}$ Tokyo District Court 23 December 1955, 6 Kaminshu No.12 p.2679; Tokyo High Court 18 July 1957, 8 Kaminshu No. 7 p.1282; interlocutory judgment of Tokyo District Court 23 June 1987, Hanreijiho No. 1240 p.27; Tokyo District Court 27 May 1965, 16 Kaminshu No.5 p.923; interlocutory judgment of Osaka District Court 9 October 1973, Hanreijiho No.728 p.76; interlocutory judgment of Tokyo District Court, Hanrei Taimuzu No. 703 p. 246.

${ }^{75}$ Interlocutory judgment of the Tokyo District Court 30 May 1989, Hanrei Taimuzu No.703 p.240; Tokyo District Court 15 February 1984, Hanrei Taimuzu No.525 p.132; Tokyo District Court 29 January 1991, Hanreijiho No. 1390 p. 98 (English translation in 35 JAIL (1992) 171).

${ }^{76}$ DAGAUCHI MASATO, 'Kokusaiteki Sosho Kyogo' [International concurrent litigation], 100 Hogaku Kyokai Zasshi [Journal of the Jurisprudence Association, University of Tokyo] 771.

${ }^{77}$ ISHIGURO KAZUNORI, 'Gaikoku ni okeru Sosho Keizoku no Kokunaiteki Koka' [Effects of lis alibi pendens in Japan], in AOYAMA and SAWAKI (eds.), op.cit. n.58 p.361.
} 


\subsection{Immunities ${ }^{78}$}

The judicial power of Japan in principle reaches all legal subjects within the territory of Japan. By way of exception foreign states are exempt from litigation, based on the principle of sovereign or state immunity. Against the background of par in parem non habet imperium, immunity was understood to be absolute. Par in parem non habet imperium has, however, been losing its validity since states often commit themselves in the field of trade or economics. As a result, the traditional principle of absolute immunity has been replaced in many countries by restrictive immunity. ${ }^{79}$ In Japan, an early decision of the Great Court of Cassation adhered to the principle of absolute immunity, ${ }^{80}$ and this position has never officially been changed. A number of judgments of lower courts after World War II followed this lead. ${ }^{81}$ The Japanese executive branch has never made its official position clear, but from the fact that Japan has concluded a number of bilateral treaties which contain provisions based on the principle of restrictive immunity, ${ }^{82}$ the Japanese government may be said not to be rigid in its attitude. ${ }^{83}$

The majority of authors support the principle of restrictive immunity ${ }^{84}$ and according to one author this principle has even become part of international customary law. ${ }^{85}$ Following this opinion, acta jure imperii and acta jure gestionis should be distinguished, and the foreign state should enjoy immunity only for the first type of acts. As to the criteria for the distinction, the leading view looks at the nature of the state act, i.e. whether the act can be carried out only by the state or also by private persons ${ }^{86}$ Since this criterion is very abstract, some typical cases are examined here:

(1) Immunity is not granted in cases concerning real property (except embassies and military bases), succession, tax or intellectual property, since the forum state's interests in these matters should be protected.

(2) The foreign state does not enjoy immunity in cases relating to labour or sales contracts. ${ }^{87}$

${ }^{78}$ TSUTSUI WAKAMIZU, 'Subjects of international law in the Japanese courts', 37 ICLQ (1988) 325 .

${ }^{79}$ The USA and major European countries including France, Germany and the UK adhere to the principle of restrictive immunity.

${ }^{80}$ Great Court of Cassation 28 December 1928, 7 Minshu 1128.

${ }^{81}$ Fukuoka High Court 15 March 1956, 7 Kaminshu No.3 p.629; Tokyo District Court 19 September 1960, 11 Kaminshu No. 9 p. 1931.

${ }^{82}$ E.g. the Treaty of Friendship, Commerce and Navigation between Japan and the USA (1953), Art. 18(2).

${ }^{83}$ TAIJUDO KanAE, Minji Saibanken no Menjo [Sovereign Immunity], in op.cit. n. 33 p. 50.

${ }^{84}$ TAKAKUWA AKIRA, Minji Saibanken no Menjo [Sovereign immunity], in AOYAMA and SAWAKI, op.cit. n.58 p.170.

${ }^{85}$ DOGAUCHI, loc.cit. n.44 p.96.

${ }^{86}$ YAMAMOTO, loc.cit. n. 21 p.436.

${ }^{87}$ Some judgments have accepted immunity of international organizations in cases concerning labour contracts: Tokyo District Court 21 September 1977, Hanreijiho No.884 p.77 (relating to the United Nations University, English translation in 23 JAIL (1980) 196); Tokyo High Court 12 
(3) The foreign state does not enjoy immunity for commercial activities. According to one interpretation, a state activity should be qualified as 'commercial', if the activity brings "profit" to the state. ${ }^{88}$

(4) In tort cases, the foreign state enjoys immunity only if the tort is caused by the foreign state as a result of its sovereign act.

These rules are applicable only to foreign states that Japan has recognized, and should also apply to international organizations, foreign municipalities and public corporations.

Foreign diplomats also enjoy immunity ${ }^{89}$ since their functions require them to be able to perform their duties as a diplomat smoothly. Japan is a party to several treaties concerning diplomatic immunity. ${ }^{90}$ According to the Great Court of Cassation, ${ }^{91}$ the service of procedural documents is a function of the sovereign power of the forum state, and to serve such documents on the representative of a foreign state would violate the sovereignty of that foreign state. ${ }^{92}$

The Japanese court must examine ex officio if it may exercise judicial power over the foreign state. The plaintiff must prove that the act of the foreign state is not a sovereign act. Under normal procedure, the defendant would have to prove the sovereign nature of his act. ${ }^{93}$

The foreign state can waive the privilege of immunity. Although the Great Court of Cassation ${ }^{94}$ held the view that the waiver should take place by agreement between the two states after the commencement of the litigation, it can in fact be made by a statement of the foreign state to the private party before the litigation.

\subsection{How to examine jurisdiction?}

The examination by the court whether it may exercise jurisdiction usually starts with an objection raised by the defendant. ${ }^{95}$ The hearing on the issue of

December 1983, 34 Rominshu No.5-6 p.922 and Tokyo District Court 31 May 1982, 33 Rominshu No. 3 p.472 (Representative of the European Community).

${ }^{88}$ YAMAMOTO, loc.cit. n. 21 p. 437.

${ }^{89} \mathrm{See}$, as precedents on this issue, Yokohama District Court 16 July 1924, Horitsu Shinbun No.2294 p.7; Tokyo District Court 29 September 1965, Hanrei Taimuzu No.184 p.170; Yokohama District Court 4 March 1987, Hanreijiho No.1225 p. 45.

${ }_{90}$ Vienna Convention on Diplomatic Relations (1961) Art.31; Vienna Convention on Consular Relations (1963) Art.43; Japan-US Consular Convention (1964) Art.11; Japan-UK Consular Convention (1965) Art.14; Japan-USSR Consular Convention (1967) Arts.18 and 27; Agreement under Article VI of the Japan-US Treaty of Mutual Cooperation and Security regarding Facilities and Areas and the Status of United States Armed Forces in Japan (1960) Art.18. Concerning the 1961 Vienna Convention, see Tokyo High Court, 8 April 1970, 21 Kaminshu No.3-4 p. 557.

${ }^{91}$ Supra n. 80.

${ }^{92}$ For a critical opinion on this judgement, see ODA SHIGERU and IWASAWA YUJI, 'Saibanken Menjo (1)' [State Immunity], in op.cit. n.64 p.193.

${ }^{93}$ Y АМАМОТО, loc.cit. n.21 p.438.

${ }^{94}$ Supra, n. 80.

${ }^{95}$ In cases where the 1953 Convention for the Unification of Certain Rules relating to International Transportation by Air, its 1967 Additional Protocol or the 1969 Convention on Civil Liability for 
jurisdiction takes place prior to that on the merits. This sequence (objection hearing on jurisdiction - hearing on merits) also applies where the relevant facts serving as the basis for the exercise of jurisdiction and the facts on the merits are closely connected. The exercise of jurisdiction in a tort case, for example, requires the determination of the place of the tort. At this stage, however, it suffices to prove that the alleged tortious act has been committed, or the damage resulting from the act was caused, in the forum state. It is not necessary to prove negligence or, for that matter, legal capacity of the defendant. Therefore, as to the degree of proof, it is sufficient for the court to believe that exercise of jurisdiction and hearing on the merits would bring no irrational burden to the defendant.

The burden of proof of the facts which serve as the basis of jurisdiction should be borne by the plaintiff. Once jurisdiction is confirmed on the basis of the facts at the time of filing, it can no more be influenced by later changes of the facts.

The unsatisfied party may appeal against a final judgment which denies or confirms jurisdiction but there is no provision in the CCP on appeal against an interlocutory judgment confirming jurisdiction. ${ }^{96}$

\section{SERVICE OF PROCESS ${ }^{97}$}

\subsection{Service abroad of process in Japan}

If service of process is seen as a function of the sovereign power of the state, ${ }^{98}$ it cannot be performed on persons outside Japanese territory. Therefore, according to Article 108 of the new CCP (Art. 175 of the old CCP), the chief judge of the court commissions the responsible foreign official or the Japanese diplomatic representative in the foreign state to perform service of process. Japan has concluded bilateral ${ }^{99}$ or multilateral agreements for this purpose. ${ }^{100}$.

Service by public notice may be made, when none of the means of international judicial assistance is available, or when the commissioned foreign official does not send a document as proof of performance of service within six months

\footnotetext{
Oil Pollution Damage applies, or in cases where a foreign forum has exclusive jurisdiction over the case, the claim can be dismissed even without the defendant's objection to jurisdiction.

${ }^{96}$ One opinion supports the possibility of appeal against an interlocutory judgment, while according to another opinion appeal would cause terrible delay of the proceeding. See TAKAHASHI HIROSHI, loc.cit. n.58 p.57; YAMAMOTO, loc.cit. n.21 p.449.

${ }^{97}$ OHARA YOSHIO, 'Judicial assistance to be afforded by Japan for proceedings in the United States', The International Lawyer (1989) 10.

${ }^{98}$ Great Court of Cassation, supra $\mathrm{n} .80$.

${ }_{99}$ As on 1 January 1992 Japan had concluded bilateral agreements on service abroad with the following countries: UK, Italy, Austria, Switzerland, Denmark, Germany, Norway, Iraq, Iran, Australia, Kuwait, Syria, Sri Lanka, Thailand and Brazil.

${ }^{100}$ The Hague Convention on Civil Procedure (1954) and the Hague Convention on the Service Abroad of Judicial and Extrajudicial Documents in Civil and Commercial Matters (1965).
} 
since the commissioning by the Japanese court (Art. 110(1) sub-paras. (3) and (4) new CCP). Article 15 of the 1965 Hague Service Convention allows service by public notice while Article 16 provides for appeal within two months by the party who was not aware of the litigation in Japan (Art. 97 new CCP). ${ }^{101}$

In domestic litigation, service may be performed by registered mail (Art. 107 new CCP). Under this system, the service is deemed to be made at the time of mailing. According to one opinion, this form of service should be available also for service on a party in a foreign state. ${ }^{102}$ But, making it so available would ignore the character of this type of service as a last resort. Furthermore, if service abroad may be easily performed in this way, the commencement of litigation will often not be notified to the other party. ${ }^{103}$ Therefore, it should not be allowed for service on a party abroad.

\subsection{Service in Japan of process abroad}

This issue will be discussed together with the requirements of recognition of foreign judgments, infra 5.1 .

\section{TAKING OF EVIDENCE ABROAD}

\subsection{Taking of evidence in foreign states}

Since the taking of evidence is also a sovereign function, it must be commissioned to a responsible foreign official or the Japanese diplomatic representative (Art.184 new CCP). Evidence may be taken by Japanese consular officers in the foreign state in the context of judicial assistance and on the basis of consular conventions. Under the system of the 1970 Hague Convention on the Taking of Evidence Abroad in Civil or Commercial Matters an organ designated by each contracting state takes the evidence upon request from another state. Since Japan has not ratified the Hague Convention, the taking of evidence is only possible on the basis of bilateral treaties. ${ }^{104}$ According to Article 184 of the new CCP, a Japanese consul may take any voluntary testimony from any person in a foreign state in accordance with Japanese law, but without violating the law of the foreign state. Nobody can be forced to appear as a witness, and

\footnotetext{
${ }^{101}$ In Supreme Court 26 May 1961, 15 Minshu No.5 p.1425, service was performed by public notice instead of service abroad. The defendant did not know of the filing of a lawsuit nor of the judgment. After he became aware through the enforcement against his car, he appealed within two months. The Supreme Court considered the appeal lawful.

${ }^{102}$ ISHIGURO KAZUNORI, op.cit. n.38 p.224.

${ }^{103}$ YAMAMOTO, loc.cit. n. 21 p. 454.

${ }^{104}$ As on 1 January 1992 Japan had concluded bilateral agreements on taking of evidence with the following countries: USA, UK, Israel, Italy, Switzerland, Sweden, Spain, Denmark, Germany, Pakistan, Iraq, Iran, India, Kuwait, Syria, Sri Lanka, Thailand and Brazil.
} 
if a person does appear, he may refuse to take an oath. And even if he makes a false statement on oath, the Japanese criminal law would not apply. ${ }^{105}$

Article 184(2) of the new CCP declares the evidence to be valid, even if taken in a manner which violates the foreign law, as long as it is in accordance with the Japanese law. The opposite case, i.e. the taking of evidence in violation of Japanese law, is not much discussed. When the fundamental principles of Japanese civil procedure are violated, the evidence should be considered unlawful. ${ }^{106}$

\subsection{Taking of evidence in Japan}

Foreign countries can, in reverse direction, use the same judicial assistance mechanisms. The often debated issue in other civil law countries concerns the unilateral taking of evidence outside the framework of a treaty on judicial assistance, such as discovery in US law. When a foreign court orders a party or a third party to produce evidence in their possession in Japan, the question arises whether the order must be followed. Although in practice Japanese companies may have followed discovery orders, there is no court decision on this issue nor any official statement about the attitude of the Japanese government. It is suggested that the order be classified as a violation of Japanese sovereignty.

\subsection{Application of foreign law}

When the applicable law designated by the Horei, the Japanese private international law, is a foreign law, the Japanese court must apply it ex officio even if the party concerned fails to prove its content. Therefore, even if both parties agree on the contents of the foreign applicable law, the court can yet determine otherwise. In order to fulfil its obligation, the court may conduct its own res arch, consult various organizations or call expert witnesses to clarify the content of the foreign law, and it may ask for the parties' assistance. The parties do not have a burden of proof, and failure of proof does not lead to any disadvantage for them. On the other hand, the court is not bound by any 'proof'. ${ }^{107}$

The Japanese court must interpret the foreign applicable law as if it were a court of the foreign state. This means that the foreign applicable law is not transformed into Japanese law, but applied as foreign law per se.

\footnotetext{
${ }^{105}$ Perjury is not included in the list of crimes to which the Japanese criminal law applies extraterritorially. See Arts. 2 and 3 of the Japanese Criminal Code.

106 E.g. the case where the opposite party could not attend the examination of witness. YАMAMOTO, loc.cit. n.21 p.470.

${ }^{107}$ KaWAMATA YoShIYA, 'Gaikoku Ho no Naiyou no Shomei' [The proof of the contents of foreign law], in SAWAKI and AKIBA, op.cit. n. 71 p. 71.
} 
Despite the efforts of the court, the foreign law may remain unknown or unclear. Yet, since the principle jus novit curia applies also to foreign law, the court must render judgment. According to the prevailing view, the law most probably resembling the foreign law should be applied. ${ }^{108}$ This resemblance should be judged on the basis of the historical, ethnical and cultural backgrounds of the foreign state. For example, where the law of North Korea is to be applied the laws of South Korea and socialist countries such as China should be taken into consideration. ${ }^{109}$ The practical outcome of this method is not always clear. In fact, there is a judgment in which Japanese law was applied instead of North Korean law although the court adhered to the prevailing view referred to above. ${ }^{110}$ Obviously, the prevailing view is not always practical for the courts. As a consequence, another view, emphasizing practicability for the courts, is becoming popular. ${ }^{111}$ According to this view, Japanese law as the lex fori should be applied. ${ }^{112}$ Unfortunately, this approach may lead to the automatic application of the lex fori and may spoil the fundamental principle of conflict of laws, i.e. the equal status of the foreign and national laws.

According to the prevailing view, when the court misinterprets the foreign law, a re-appeal to the Supreme Court may be made. ${ }^{113}$ The same is the case when the court has failed to take appropriate measures to find the contents of the foreign law and has rendered a judgment by applying the lex fori. ${ }^{114}$ The Japanese Supreme Court has not taken a clear stand, but the possibility of reappeal is assumed through interpretation of its jurisprudence. ${ }^{115}$ As a result of its reform, the CCP now grants the Supreme Court more discretion in accepting re-appeals. It remains to be seen how generously the Supreme Court will allow re-appeal in cases concerning the application of foreign law.

\footnotetext{
${ }^{108}$ Ibid. See also Tokyo Family Court 13 June 1963, 15 Kasaigeppo No.2 p.163; Tokyo District Court 25 October 1962, Hanreijiho No. 321 p. 23.

${ }^{109}$ KidANA in KiDANA et. al., op.cit. n. 60 p. 71.

${ }^{110}$ Nagoya Family Court 12 March 1982, 35 Kasaigeppo No.1 p.105.

"II MIKAZUKI AKIRA, 'Gaikoku Ho no Tekiyou to Saibansho' [The application of foreign law and the Japanese court], in SAWAKI and AOYAMA, op.cit. n.58, p.269; YAMAMOTO, loc.cit. n.21 p.459. The same view is expressed in some judgments: Nagoya District Court 7 October 1975, Hanreijiho No. 817 p.98; Kyoto District Court 30 September 1987, Hanreijiho No.1275 p.114.

${ }^{112}$ As a result Japanese law was applied in the judgment of the Nagano Family Court 12 March 1982, 35 Kasaigeppo No. 1 p.105.

${ }^{113}$ KAWAMATA, loc.cit. n.107.

${ }^{114}$ Ibid.

${ }^{115}$ Supreme Court 2 July 1981, 35 Minshu No.5 p.81.
} 


\section{RECOGNITION OF FOREIGN JUDGMENTS ${ }^{116}$}

Like the topic of international jurisdiction, the recognition of foreign judgments raises many important theoretical and practical matters. The 1996 reform of the CCP on this issue (Arts. 200 of the old CCP and 118 new CCP) was minimal and consequently the theories developed so far and existing court decisions will continue to play an important role.

The victorious party in a foreign lawsuit against a person with assets in Japan is interested in having his rights under the foreign court's judgment realized through execution on the assets in Japan. For that purpose he needs an exequatur judgment required by Article 24(2) of the Law of Civil Execution. ${ }^{117}$ Under this provision the foreign judgment must fulfil the requirements of Article 118 of the new CCP (Art. 200 of the old CCP). The discussion of these requirements will be the core of the present section. Another feature of the provision is the prohibition of revision au fond: any substantive examination of the foreign judgment as to the propriety of its solution in the specific case is excluded. ${ }^{118}$

\subsection{Requirements for the recognition of foreign judgments}

\subsubsection{Jurisdiction of the foreign court}

The principal requirement is that the foreign forum was entitled to exercise international jurisdiction. This jurisdiction is described as 'indirect' international jurisdiction in contrast to the jurisdiction dealt with earlier. Article 200(1) of the old CCP, which stated that "the jurisdiction of a foreign court is not denied by law or by treaty", was amended and according to Article 118(1) of the new CCP "the jurisdiction of a foreign court is admitted by law or by treaty". Under the old CCP, a minor view held that it is not necessary for the existence of jurisdiction of the foreign court to be confirmed, ${ }^{119}$ but under the new CCP such a view cannot be maintained.

\footnotetext{
${ }^{116}$ KONO TOSHIYUKI and ALEXANDER TRUNK, 'Anerkennung und Vollstreckung ausländischer Urteile in Japan' [Recognition and enforcement of foreign judgements in Japan], 102 Zeitschrift für Zivilprozessrecht (1989) 319. TAKESHITA MORIO, 'Neuere Tendenzen der Anerkennung und Vollstreckung ausländischer Entscheidungen in Japan, 109 Zeitschrift für Zivilprozessrecht (1996) 305 et seq.; SAWAKI TAKAO, 'Recognition and enforcement of foreign judgments in Japan', The International Lawyer (1989) 29.

117 For an overview, see ISEKI MASAHIRO and HIGASHI TAKAYUKI, 'Civil Execution', in Kitagawa Zentaro (ed.), 16 Doing Business in Japan Ch. 6.

${ }^{118}$ This is sometimes referred to as 'automatic recognition'. See WATANABE, in KIDANA et al., op.cit. n. 60 p. 280 . It may, however, be misleading. Although it raises the impression that all effects of the foreign judgment under the foreign law are automatically recognized, this is not always the case. E.g. the range of res judicata may be vastly different in Japan and in other states.

${ }^{119}$ See KoSUGI TAKEO, in SAWAKI and AKIBA, op.cit. n. 71 p. 234.
} 
A key issue concerns the criteria by which to confirm indirect jurisdiction. According to the prevailing view, ${ }^{120}$ the rule governing the question of jurisdiction of the Japanese court should also apply to the recognition of foreign judgments. ${ }^{121}$ This means that the jurisdiction of a foreign court must be determined from the Japanese perspective, since rendering and recognizing a judgment are essentially the same functions. There is, however, another opinion which allows the application of different rules to the question of indirect jurisdiction, especially in case of divorce judgments. Situations in which a marriage is valid in country A but not in Japan could be avoided through a generous attitude towards recognition of foreign judgments. ${ }^{122}$ Finally, a third view suggests the establishment of specific rules on indirect jurisdiction. ${ }^{123}$

Following the leading opinion, the rules which are explained in section 1 of this paper apply to indirect jurisdiction.

\subsubsection{Service and appearance}

These requirements serve the protection of the defendant who has not been notified about the commencement of the foreign litigation and who has, therefore, not been able to prepare his defence. Although they have remained the same under the new CCP, there are two minor differences between Article 200(2) of the old CCP and Article 118(2) of the new CCP. First, Article 200(2) only covered the service on defendants who are Japanese nationals. This nationalistic bias has been abolished. Secondly, while the old CCP regarded only service by public notice as an inappropriate means of service, under the new CCP other equivalent means of service may also be classified as inappropriate. Consequently, Article 118(2) of the new CCP may be broadly interpreted as regulating not only the service, but also other procedural issues relating to due process.

With regard to the requirements, service by mail from the USA has raised an important theoretical and practical issue. ${ }^{124}$ Under Article 10 item (a) of the 1965 Hague Service Convention, each contracting state could declare its objection to, and consequently refuse service from abroad, by mail. Japan has not made such objection, giving rise to a number of questions. When a company or a person in Japan receives judicial documents by mail directly from an American attorney of the plaintiff, should it be deemed "service" within the meaning

\footnotetext{
${ }^{120}$ WATANABE, in KIDANA et al., op.cit. n. 60 p. 286.

${ }^{121}$ Some judgments have followed this approach. See Tokyo District Court 19 September 1980, Hanrei Taimuzu No.435 p.155; Osaka High Court 25 February 1992, 45 Kaminshu 29 (English translation in 39 JAIL (1993) 217).

${ }^{122}$ See YAZAWA SHOJI, in IKEHARA and HAYATA, op.cit. n. 64 p. 227.

${ }^{123}$ Ibid.

${ }^{124}$ Besides Heldrich and KoNO, op.cit. n.1, see also William TEMPLE JORDAN, 'Beyond jingoism: service by mail to Japan and the Hague Convention on Extrajudicial Documents in Civil or Commercial Matters', 16 Law in Japan (1983) 69; FUJITA YASUHIRO, 'Service of American process upon Japanese nationals by registered airmail and enforceability of resulting American judgments in Japan', 12 Law in Japan (1979).
} 
of Article 200(2) of the old CCP (Art. 118(2) new CCP)? If so, is it always considered valid or only under certain circumstances?

There are two views on the matter: according to one it is "service" within the meaning of the CCP, since Japan has not raised an objection under Article 10 of the Hague Convention. The validity of the service by mail should be determined by whether or not a translation has been attached ${ }^{125}$ and by various elements of the case, such as the language ability of the defendant, or by the type of case. ${ }^{126}$

According to the other opinion, taking the concrete circumstances of each case into consideration in order to determine the validity of service would lead to uncertainty of procedure. The service should rather be considered invalid or simple de facto notice. ${ }^{127}$

According to the official position of the Japanese government, the fact that Japan has not made the declaration only means that Japan will not consider service by mail to be violative of Japanese sovereignty, but does not mean that Japan recognizes it as a measure of service. ${ }^{128}$ Some court decisions have held that service by mail without translation does not meet the requirements of Article 200(2) of the old CCP. ${ }^{129}$ It is, therefore, recommended to use the judicial assistance procedures or, at least, attach a Japanese translation to service by mail.

\subsubsection{Public policy}

Article 200(2) of the old CCP as well as Article 118(2) of the new CCP lays down that foreign judgments shall not violate Japanese public policy. Not only the CCP, but also the Horei (Art. 33) and the Japanese Civil Code (Art. 90) use public policy as an instrument to protect the fundamental values of Japanese law. However, public policy in the CCP (and in the Horei) protects more fundamental values than public policy in Article 90 of the Japanese Civil Code. ${ }^{130}$ The Japanese court is to examine ex officio whether a foreign judg-

${ }^{125}$ TAKAKUWA AKIRA, 'Shogaiteki Minji Sosho Jiken ni okeru Sotatsu to Shokoshirabe' [Service and taking of evidence in transboundary civil litigation], 37 Hosojiho [Lawyers Association Journal] (No. 4) 54.

${ }^{126}$ KONO TOSHIYUKI, commentary on the judgment of the Tokyo District Court, 11 November 1988, Jurisuto No. 957 p.282.

${ }^{127}$ FUJITA YASUHIRO, 'Nihon no Hikoku ni taisuru Amerika Sojo no Chokusetsu Yuso to sono Koryoku' [Service by mail from USA to Japanese defendants and its effect], Hanrei Taimuzu No.354 p.84; MIKAZUKI AKIRA, in Yuasa law firm (ed.) Kokusaitorihiki to Keiso no Horitsujitsumu [International Trade and Legal Practice of Conflicts] p. 480.

${ }^{128}$ HARA MASARU, 'Shiho no Kokusaiteki Toitsu Undo' [International unification of private law], 17 Kokusai Shoji Homu [Journal of the Japanese Institute of International Business Law] (No.12) 1287.

${ }^{129}$ Tokyo District Court 21 December 1976, 27 Kaminshu No. 9-12 p. 801; Tokyo District Court 11 November 1988, Hanreijiho No. 1315 p. 96 (English translation in 33 JAIL (1990) 208); Tokyo District Court 26 March 1990, Kinyu Shoji Hanrei No. 1857 p.39 (English translation in 34 JAIL (1991) 174).

${ }^{130}$ TAKAKUWA AKIRA, 'Gaikoku Hanketsu Shouinyoken toshiteno Kojoryozoku' [Public policy as a 
ment violates Japanese public policy. In this examination, not only the formal aspects of adjudication, but also the facts underlying the ratio decidendi may be taken into consideration. It must, however, not be a révision au fond, although as a matter of fact the public policy test may lead to révision au fond. ${ }^{131}$

After the amendment of Article 200(3) of the old CCP, Article 118(3) of the new CCP now prescribes that the content and the procedure of judgments (of foreign courts) shall not violate the public policy of Japan. Accordingly, the public policy test will also be made from the procedural point of view. Not only judgments with unacceptable contents, but also judgments rendered on the basis of a very unfair procedure, cannot be recognized. The prevailing view under the old CCP adhered to this standpoint too and the Supreme Court endorsed it in an obiter dictum. ${ }^{132}$ It is now the official position of the Japanese law. Lack of judicial independence, lack of equal opportunity for both parties to examine the evidence, or lack of opportunity for those supervising against the forging of evidence are often mentioned as examples of procedures violating Japanese public policy. ${ }^{133}$ The qualification 'violating public policy' can only be made on a case-by-case basis, since the ultimate criterion of fairness of the procedure cannot be defined in an abstract manner. ${ }^{134}$

One of the most debated issues concerning public policy is the recognition of American so-called 'punitive damages judgments'. These judgments tend to order the defendant to pay enormous amounts of money. The purpose of these judgments, i.e. deterrence of unlawful acts or punishing the defendant, is foreign to Japanese civil procedure. The matter can be sub-divided into two issues:

(1) Since recognition of foreign judgments deals exclusively with 'civil' judgments, ${ }^{135}$ it should be asked whether a judgment awarding punitive damages can be classified as a 'civil' judgment? If the answer to this question is in the negative, the recognition of punitive damages judgments is generally excluded. ${ }^{136}$

requirement for the recognition of foreign judgments], in AOYAMA and SAWAKI, op.cit. n. 84 p. 237.

${ }^{131}$ For a problematic case in this sense, see the judgment referred to in $\mathrm{n} .139$.

${ }^{132}$ Supreme Court 7 June 1983, 37 Minshu No. 5 p. 611.

${ }^{133}$ Yokohama District Court 24 March 1989, Hanrei Taimuzu No. 703 p.268. In its decision of 22 December 1977, the Osaka District Court, Hanrei Taimuzu, No. 361 p. 127, refused to recognize a judgment rendered in the State of Washington, USA. The reasoning was that an existing judgment in Japan had led to a different result and that recognition would violate Art. 200(2) of the old CCP. The majority of scholars endorse this position. See TAKAKUWA, loc.cit. n.130.

${ }^{134}$ TAKAKUWA, ibid. Notice of litigation or guarantee of defence possibilities is covered by Art. $118(2)$.

${ }^{135}$ Neither Art. 200 old CCP nor Art. 118 new CCP explicitly mentions the 'civil' nature of foreign judgements as a requirement for their recognition. This is, however, the general understanding.

${ }_{136}$ DOGAUChI MASATO, Hanreijiho No.1388 p.202; HaYAKaWA YOSHIHISA, 'Chobatsuteki Songaibaisho Hanketsu no Shonin Shikko' [The recognition and execution of punitive damage judgments], Hongo Hosei Kiyo [Journal of Law and Politics of Tokyo University Graduate Students] No.1(1993) 257; ISHIGURO KAZUNORI, 'America no Chobatsuteki Songaibaisho to 'Kokkyo' [US punitive damages and the border], Boeki to Kanzei [Trade and Tax] (October 1994) 
(2) Should the judgment be classified as 'civil', would recognition violate Japanese public policy? If it does, should the recognition of the whole judgment be refused ${ }^{137}$ or could part of the judgment be recognized? ${ }^{138}$ In the latter case, the question is how to determine the part of the judgment (especially the punitive damages awarding part) which could be recognized, since re-examination of the case is impossible due to the prohibition of revision au fond. The Tokyo District Court refused recognition of the punitive damages award part of a Californian judgment (compensatory damages were fixed at US\$ 420,000 and punitive damages at US $\$ 120,000) .{ }^{139}$ The judgment has been criticized for actually performing révision au fond. ${ }^{140}$ It is certainly not easy to draw a clear border line between the public policy test and révision au fond, if partial recognition is to be granted. Therefore, the opinion is held that beyond a certain level acceptable in Japan, the award should be assumed to be foreign to Japanese law. Consequently, the victorious party should bear the burden of proof that this latter part is also acceptable in Japan. ${ }^{141}$ During appeal from the judgment of the Tokyo District Court, the High Court said that it was doubtful that the judgment could be the object of recognition due to the criminal law nature of the punitive damages award. Even if it could, the recognition and execution would violate public policy. ${ }^{142}$

\subsubsection{Reciprocity}

According to an old judgment, ${ }^{143}$ reciprocity exists between Japan and a foreign state when the foreign state recognizes Japanese judgments under the same requirements as those of the Japanese (old) CCP or under more generous requirements. This interpretation was criticized for the following reasons. First, a strict application would disturb mutual recognition rather than achieve a more generous attitude of both states to each other. Second, it is sometimes difficult to determine which state is more generous in recognizing foreign judgments, since requirements for recognition differ in each country. Thirdly, if a foreign judgment cannot be recognized due to the requirement of reciprocity, the price

40.

137 FUjITA YASUHIRO, 'Shogai Minjijiken no Jitsumu to Mondaiten' [Practice and issues in international civil cases], 31 Jiyu to Seigi [Liberty and Justice] No.11 (1980) 18.

${ }^{138}$ KONO TOSHIYUKI, 'Amerika no Chobatsuteki Baisho Hanketsu to Kokusai Minjisoshoho jo no jakkan no Mondai nitsuite' [US punitive damages judgment and several issues of international civil procedure], 58 Hosei Kenkyu [Journal of Law and Politics, Kyushu University] No. 4 (1991) 867; KOBAYASHI HIDEYUKI, 'Chobatsuteki Songaibaisho to Gaikoku Hanketsu Shonin' [Punitive damages and the recognition of foreign judgments], NBL No. 473 (1991) 6; see also No. 477 p. 20. ${ }^{139}$ Decision of 18 February 1991, Hanreijiho No.1376 p.79. (English translation in 35 JAIL (1992) 177).

${ }^{140}$ ISHIGURO KAZUNORI, in Shiho Hanrei Rimakusu [Remarks on Civil Law Judgments] No.4 (1992) 167.

${ }^{141}$ KONO, loc.cit. n.138.

${ }^{142}$ Tokyo High Court 28 June 1993, Hanreijiho No.1471 p.89 (English translation in 37 JAIL (1994) 155).

${ }^{143}$ Great Court of Cassation 5 December 1933, Horitsushinbun No.3670 p.15. 
must be paid by the persons who try to materialize their rights, and this would be quite unfair. As a result, the Supreme Court modified its old opinion and now holds that, if a foreign state recognizes a similar type of Japanese judgment under conditions not essentially different from the requirements of Article 200 (of the old) CCP, reciprocity is deemed to exist between the two countries. ${ }^{144}$ Under these criteria, the judgment of a foreign state which takes a more rigorous attitude than Japan, can be recognized. In fact, reciprocity has been generously recognized by lower courts ${ }^{145}$ and is generally endorsed by scholars. ${ }^{146}$ According to some, even this liberal interpretation of reciprocity is not generous enough to enhance the recognition of foreign judgments and, consequently, the requirement should be abolished. ${ }^{147}$ However, Article 118 of the new CCP has retained the requirement. Therefore the existing discussion and case law remains relevant.

\subsubsection{Other requirements}

\subsubsection{Recognition of constitutive judgments}

Foreign judgments must be recognized to the extent that under the Civil Execution Law recognition is required for the purpose of execution. Some kinds of judgments do not need execution, however, for example divorce judgments. According to one opinion, Article 200 of the old CCP (Art. 118 new CCP) should apply mutatis mutandis and the requirement of reciprocity should be ignored in these cases. Instead, there should be a requirement that the foreign court has applied the same law as that referred to as the applicable law by Japanese private international law. ${ }^{148}$ This opinion has the following background: a judgment acquires its constitutive effect from substantive law. In case of judgments of Japanese courts in transboundary cases, this constitutive effect is derived from the foreign applicable law referred to by Japanese private international law. If the judgment is rendered by a foreign court and intended to

\footnotetext{
${ }^{144}$ Supreme Court 7 June 1983, 37 Minshu No.5 p.611 (English translation in 27 JAIL (1984) 119). Before this judgment, reciprocity was denied in two cases: Tokyo District Court 20 July 1960, 11 Kaminshu No.7 p.522 (Belgium), and Fukuoka District Court 25 March 1982, 31 JCA Journal No. 12 p.2 (Hong Kong).

145 Nagoya District Court 6 February 1987, Hanreijiho No. 1236 p. 113 (Germany) (English translation: 33 JAIL (1990) 189); Tokyo District Court 16 December 1991, Hanrei Taimuzu No. 794 p. 246 (State of Nevada); Tokyo District Court 30 January 1992, Hanrei Taimuzu No. 789 p. 259 (State of Texas); Kobe District Court 22 September 1993, Hanrei Taimuzu No. 826 p. 206 (Hong Kong); Tokyo District Court 31 January 1994, Hanrei Taimuzu No. 837 p. 300 (United Kingdom).

${ }^{146}$ KONO TOSHIYUKI, 'Shoninyoken toshiteno Sogo no Hosho' [Reciprocity as a requirement of the recognition of foreign judgments], in SAWAKI and AKIBA op.cit. n. 71 p. 239.

147 SAKURADA YOSHIAKI, in Hanreihyoron No. 288 p. 32. Against this opinion: TAKAKUWA AKIRA, in 90 Minshoho Zasshi [Journal of Civil and Commercial Law] (no. 1) 101.

${ }^{148}$ EGAWA HIDEFUMI, 'Gaikoku Hanketsu no Shonin', 50 Hogaku Kyokai Zasshi [Journal of the Jurisprudence Association, University of Tokyo] (no. 11) 2054. See also: Tokyo District Court 15 March 1961, 12 Kaminshu No. 3 p. 486.
} 
be recognized in Japan, it should fulfil the same condition, i.e. having applied the same law as the Japanese court would apply (the so-called applicable law requirement).

Another school of thought applies Article 200 of the old CCP (Art. 118 new $\mathrm{CCP})$ mutatis mutandis without the applicable law require-ment, ${ }^{149}$ i.e. items 1 , 2 and 3 of the Article.

The prevailing opinion applies Article 200 of the old CCP (Art. 118 new $\mathrm{CCP}$ ) in its entirety, including the reciprocity requirement but without the applicable law requirement. ${ }^{150}$ As far as the requirement of reciprocity is interpreted generously, as stated above, it does not make sense to ignore this requirement. Therefore, under the new CCP the prevailing opinion should also be followed.

\subsubsection{Final judgments}

Article 200 of the old CCP (Art. 118 new CCP) refers to 'final' judgments. 'Final' means the state of judgment where neither annulment nor alteration is allowed any more. Therefore, among other things, recognition of arrest, being a provisional measure, is not allowed under the current system.

\subsubsection{Foreign courts}

The foreign judgment must have been rendered by a court or institution of the foreign state vested with judicial power. It may be an administrative organ, as long as it possesses judicial power. Settlement made in court does not fulfil this requirement, since it is based on agreement between the parties and not the result of the exercise of judicial power.

\subsection{Effects of the recognition of foreign judgments}

The recognition of a foreign judgment, according to prevailing opinion, extends the effects conferred to the judgment by the law of the foreign state. ${ }^{151}$ This view is closely connected with the notion of automatic recognition. ${ }^{152}$ When the foreign judgment fulfils the requirements of Article 200 (old, now 118 new) of the CCP, it is deemed to be "automatically" recognized and accordingly its effects extend to the Japanese legal order. There is a possibility, however, of limiting these effects as far as they are very different from those under Japanese law. For example, the range of res judicata may be vastly different in the two legal systems. Therefore another opinion, according to

\footnotetext{
149 TAMAIKE YoshIO, Kokusaishiho Kogi [Lectures of Private International Law] (1995) 454. See also Yokohama District Court 7 September 1971, Hanreijiho No. 665 p. 75.

150 YAMADA RYOICHI, Kokusaishiho [Private International Law] (1992) 406. See also Tokyo District Court 17 December 1971, Hanreijiho No. 665 p. 72.

${ }^{151}$ See WATANABE, in KiDANA et al., op.cit. n. 60 p. 281.

${ }^{152}$ See the introductory part on recognition of foreign judgments in this paper.
} 
which recognition implies the conferment of effects to the judgment by Japanese law, is also persuasive. This has not yet been sufficiently discussed so far and will be an important future issue.

\subsection{Procedure of exequatur}

The examination of whether a foreign judgment fulfils the requirements of Article 200 (old, now 118 new) of the CCP, is part of the exequatur procedure. From a theoretical point of view the exequatur procedure originates in a claim for a constitutive judgment granting executive effects to the foreign judgment. A normal hearing and the regular evidence examination procedure take place. No examination is, however, undertaken as to the question of whether the foreign judgment was an appropriate solution of the concrete case (prohibition of revision au fond). When the situation of the case has changed after the judgment, ${ }^{153}$ the defendant can assert such changes by way of an objection against the execution. ${ }^{154}$

\section{ARBITRATION}

\subsection{Law applicable to international arbitration}

According to the majority of Japanese court decisions on the subject, an arbitral agreement is a kind of contract in the field of civil law. ${ }^{155}$ Therefore, the applicable law is to be determined by the Horei, ${ }^{156}$ unless international conventions apply. ${ }^{157}$

When the validity of an arbitral agreement is in question in the context of the recognition of a foreign arbitral award, the law applicable to the question of validity is determined by Article 5(1)(a) of the 1958 New York Convention on the Recognition and Enforcement of Foreign Arbitral Awards. If the question arises in different contexts, Article 7 of the Horei determines the applicable law by leaving the choice to the parties. In the absence of a choice, the intention of the parties should be determined. A recent judgment held that, when the parties chose the place of arbitration, they must have had the intention to apply the law of that place. ${ }^{158}$ This view finds support in the literature. ${ }^{159}$ The law applicable

\footnotetext{
${ }^{153}$ E.g. when partial payment has been made.

${ }^{154}$ Tokyo District Court 13 October 1965, 16 Kaminshu No. 10 p. 1560.

155 Supreme Court 15 July 1975, 29 Minshu No. 6 p. 106; Tokyo High Court 30 May 1994, Hanreijiho No. 1499 p. 68.

${ }^{156}$ For an overview of the Japanese conflict of laws, see FUJITA YASUHIRO, 'Transnational litigation - conflict of laws', in KITAGAWA (ed.), op.cit. n. 117 Ch. 5.

${ }^{157}$ International conventions are usually applicable when issues of applicable law are raised in the context of recognition of foreign arbitral awards.

${ }^{158}$ Tokyo High Court 30 May 1994, Hanreijiho No. 1499 p. 68.

${ }^{159}$ See e.g. KoJIMA TAKESHI and TAKAKUWA AKIRA (eds.), Chukai Chusaiho [Commentary of the Arbitration Law] (1988) 219.
} 
to the question of the validity of an arbitral agreement is also applicable to the question of the effects of the agreement. ${ }^{160}$

The applicable law in procedural matters in the field of arbitration is, according to the leading opinion, the law chosen by the parties, and, in the absence of a choice, the law of the place of arbitration. ${ }^{161}$ The majority of the available court decisions, however, apply the lex fori to the procedural effects, such as the litigation-excluding effect. ${ }^{162}$ This is also the prevailing view among scholars. ${ }^{163}$

\subsection{Recognition of foreign arbitration}

Japan is a party to multilateral and bilateral treaties on the recognition of foreign arbitral awards, ${ }^{164}$ but it has not enacted any municipal law on the implementation of these treaties. The treaties usually specify the kinds of arbitration awards covered by them and the recognition and enforcement of most international arbitration awards are dealt with on the basis of these treaties. ${ }^{165}$ When both the New York Convention and a bilateral treaty are applicable to the same case, the bilateral treaty applies if it is more generous than the New York Convention. ${ }^{166}$ In fact, many of the Japanese bilateral treaties are considered to be more generous than the New York Convention. ${ }^{167}$

When there is no treaty applicable, the Japanese lex fori should be applied. However, Articles 801 and 802 of the old $\mathrm{CCP}^{168}$ are generally considered to be applicable only to domestic arbitration. ${ }^{169}$ There are two opinions on this issue. According to the first one, there are some lacunae in the Japanese law

\footnotetext{
${ }^{160}$ See Supreme Court, supra $\mathrm{n} .155$.

${ }^{161}$ KOJIMA and Takakuwa, op.cit. n.159, p. 226; KOYAMA NOBORU, Chusaiho [Arbitration Law] (new ed., 1983) 182 and 248. See also Art. 5(1)(d) of the New York Convention.

${ }_{162}$ Tokyo District Court 10 April 1953, 4 Kaminshu No. 4 p. 502; Tokyo District Court 25 December 1973, Hanrei Taimuzu No. 308 p. 230. Cf. Tokyo High Court supra n. 158.

${ }^{163}$ Op.cit. n. 159 p. 223.

164 The most important treaty is the 1958 New York Convention on the Recognition and Enforcement of Foreign Arbitral Awards. Japan has concluded 14 bilateral treaties concerning the recognition and enforcement of foreign arbitral awards (with the USA, the Soviet Union, Poland, Yugoslavia, the Czech Republic, Pakistan, Peru, Argentina, the UK, El Salvador, Rumania, Bulgaria, China and Hungary).

${ }^{165}$ KOBAYASHI, loc.cit. n. 138 p. 256.

${ }^{166}$ New York Convention Art.7(1).

${ }^{167}$ KOBAYASHI, loc.cit. n. 138 p. 244.

168 Art.801 deals with the reasons for annulment of arbitral awards. Art.802 lays down the requirement of an exequatur judgment for the execution of arbitral awards, and proscribes exequatur in case of existence of one of the reasons for annulment. As a result of the amendment of the CCP, these provisions will be transferred to the sections on public protest procedure (German: Aufgebotverfahren) and arbitration procedure, without substantial change.

${ }^{169}$ NAKATA JUNICHI, Sosho oyobi Chusai no Hori [Legal Theory of Litigation and Arbitration] (1937) 413; KoBAYASHI, op.cit. n.40 p.210. Cf. Tokyo District Court 19 June 1995, Hanrei Taimuzu No. 919 p. 252.
} 
which should be filled by Jori. ${ }^{170}$ The other view says that Articles 801 and 802 of the old CCP should be applied also to international arbitral awards ${ }^{171}$ or should be applied mutatis mutandis. ${ }^{172}$ In the present situation, where most countries are party to treaties governing the matter, this debate has, however, very little practical meaning. Also the judgments which by way of formal reasoning applied Articles 801 and 802 of the old CCP mutatis mutandis took the requirements of the relevant treaties into consideration. ${ }^{173}$

Since there is no special procedure for the recognition of foreign arbitral awards, the procedure for domestic arbitration should be used: an application should be submitted seeking an enforcement judgment for the foreign arbitral award. When the enforcement judgment is rendered and becomes final, enforcement can take place. Dismissal of the claim for reasons of existing grounds for annulment (cf. Arts. 801 and 802 of the old CCP) does not imply the annulment of the award, since annulment requires a separate procedure.

The Legal System Council, an advisory organ for the Minister of Justice, is at present preparing a draft in the field of arbitration. It is hoped that provisions on international arbitration will be included in the draft.

\footnotetext{
${ }^{170}$ NAKATA, ibid., p. 423 . As to the requirements for Jori: the arbitration award must (1) be valid according to the law applicable to the arbitration contract and (2) not violate Japanese public policy; (3) ex parte hearing must have been held and the parties must have been appropriately represented in the procedure.

171 AGAWA KIYOMICHI, 'Gaikoku Chusai Handan no Shonin oyobi Shikko nitsuite' [The recognition and enforcement of foreign arbitral awards], Jurisuto No.232 p.42; YAMAMOTO, loc.cit. n. 21 p. 473.

${ }^{172}$ KOBAYASHI, in op.cit. n. 159 p. 243.

${ }^{173}$ Tokyo District Court 20 August 1959, 10 Kaminshu No. 8 p. 1711 (1927 Geneva Convention); Tokyo District Court 23 October 1959, 10 Kaminshu No. 10 p. 2232 (Japan-US Treaty of Friendship, Commerce and Navigation); Osaka District Court 27 November 1961, 6 Kaijihanrei No. 5 p. 118 (idem); Nagoya District Court, lchinomiya Branch 26 February 1987, Hanreijiho No. 1232 p. 138 (idem); Osaka District Court 22 April 1983, Hanreijiho No. 1090 p. 146 (New York Convention).
} 